\title{
PEMODELAN SISTEM INFORMASI LAYANAN BIMBINGAN KONSELING PADA PERGURUAN TINGGI BERBASIS PENILAIAN KOPETENSI
}

\author{
Muhammad Arifin ${ }^{1}$, Farid Noor Romadlon ${ }^{2}$ \\ ${ }^{1}$ Fakultas Teknik, Sistem Informasi, Universitas Muria Kudus \\ ${ }^{2}$ Fakultas Keguruan dan Ilmu Pendidikan, Pendidikan Bahasa Inggris, Universitas Muria Kudus
}

\section{Article Info:}

Dikirim: 15 Mei 2019

Direvisi: 19 Mei 2019

Diterima: 30 Mei 2019

Tersedia Online: 31 Desember 2019

Penulis Korespondensi:

Muhammad Arifin

Universitas Muria Kudus, Kudus, Indonesia

Email: arifin.m@umk.ac.id

\begin{abstract}
Abstrak: Jenis bimbingan konseling telah dilaksanakan oleh beberapa perguruan tinggi dalam bentuk informal yaitu melalui diskusi antar mahasiswa dan dosen sehingga menemukan permasalahan dan cara penyelesaian dari setiap permasalahan dari pelaksanaan bimbingan konseling. Diskusi yang dilakukan dengan dosen yang tidak memiliki kualifikasi ahli dibidang konseling memang kadang mampu memberikan solusi dalam memecahkan permasalahan yang ada, namun proses konsultasi semacam ini tidak terdokumentasi dengan baik dan tidak dapat dilakukan setiap saat. Sedangkan permasalahan mahasiswa-mahasiswi yang terjadi didalam perguruan tinggi bisa terjadi setiap saat. Model bimbingan berbeda-beda tetapi pada umumnya adalah menfasilitasi dan mempertemukan antara konselor dan konsi untuk melakukan bimbingan. Pada umumnya tempat layanan kurang memperhatikan keahlian yang dimiliki oleh konselor sehingga sering ditemukan konselor menangani permasalahan konseli yang tidak sesuai dengan keahlian konselor hal ini dapat menyebabkan kurang tepatnya konselor dalam memberikan solusi. Umumnya konseli tidak memiliki hak untuk memilih konselor yang memiliki keahlian yang sesuia dengan permasalahan mereka. Penelitian ini diharapkan mampu menghasilkan perancangan aplikasi sistem bimbingan konseling online dengan menggunakan pemodelan UML. Selain itu penelitian ini juga diharapkan mampu menghasilkan model bimbingan konseling secara online dengan memberikan fasilitas penilaian kinerja konselor dalam memberikan pelayanan terhadap konseli. Penilian ini nantinya dapat dijadikan tolok ukur tingkat kesuksesan konselor dalam menyelesaikan permasalahan konseli yang mereka hadapi.
\end{abstract}

Kata kunci: bimbingan konseling online; konselor; konseli.

\begin{abstract}
The type of counseling has been carried out by several universities in the form of informal, namely through discussions between students and lecturers so that they find problems and how to solve each problem from the implementation of counseling. Discussions conducted with lecturers who do not have expert qualifications in counseling are indeed sometimes able to provide solutions in solving existing problems, but this kind of consultation process is not well-documented and cannot be done at any time. While the problems of students taking place in higher education can occur at any time. The guidance is different but in general it is facilitating and bringing together the counselor and konsi to conduct guidance. In general, the service place does not pay attention to the expertise possessed by the counselor, so often found counselors handle counselee problems that are not in accordance with the expertise of the counselor, this can lead to inappropriate counselors in providing solutions. Counselees generally do not have the right to choose counselors who have expertise according to their problems. This research is expected to be able to produce an online counseling system application design using UML modeling. In addition, this study is also expected to be able to produce a model of counseling online by providing a facility to assess the performance of counselors in providing services to counselees. This assessment can later be used as a benchmark for the success level of counselors in solving the counselee problems they face.
\end{abstract}

Keywords: online guidance counseling; counselors. 


\section{PENDAHULUAN}

Kampus merupakan tempat untuk menuntut ilmu dijenjang pendidikan tinggi, didalam sebuah kampus atau perguruan tinggi terdapat banyak mahasiswa-mahasiswi yang terdiri dari berbagai program studi maupun fakultas. Mereka berasal dari daerah yang berbeda, ada yang berasal dari daerah berdekatan dengan perguruan tinggi itu sendiri ada pula yang berasal dari daerah yang jauh. Kondisi yang demikian tentunya antar mahasiswamahasiswi memiliki karakter dan kepribadian serta kebudayaan yang berbeda-beda pula.

Dengan kebudayaan, karakter dan kepribadian berbeda tentunya ketika mereka berkumpul sedikit banyak akan ada permasalahan, baik secara individu maupun permasalahan secara kelompok. Bahkan tidak sedikit mahasiswa-mahasiswi yang mengalami permasalahan dalam bentuk gangguan secara fisik maupun psikis akibat pergaulan antar sesama peserta didik. Sesuai dengan aturan kementrian ristekdikti dan instrumen didalam akreditasi baik perguruan tinggi maupun akreditasi program studi bahwa kebutuhan akan layanan bimbingan konseling harus ada, karena keberadaannya sangat dibutuhkan didalam membantu mahasiswa/i dalam membantu menyelesaikan masalah-masalah yang mereka hadapi.

Apabila mereka tidak mampu menyelesaikan permasalahan-permasalahan mereka sendiri maka mereka akan membutuhkan bantuan orang lain dalam mengatasinya. Meskipun kadangkala mereka tidak menyadari akan permasalahan mereka sendiri, hal ini dikarenakan mereka mengangangap sesuatu yang biasa.

Jenis bimbingan konseling telah dilaksanakan oleh beberapa perguruan tinggi dalam bentuk informal yaitu melalui diskusi antar mahasiswa dan dosen sehingga menemukan permasalahan dan cara penyelesaian dari setiap permasalahan dari pelaksanaan bimbingan konseling. Diskusi yang dilakukan dengan dosen yang tidak memiliki kualifikasi ahli dibidang konseling memang kadang mampu memberikan solusi dalam memecahkan permasalahan yang ada, namun proses konsultasi semacam ini tidak terdokumentasi dengan baik dan tidak dapat dilakukan setiap saat. Sedangkan permasalahan mahasiswa-mahasiswi yang terjadi didalam perguruan tinggi bisa terjadi setiap saat.

Model proses bimbingan yang terapkan disetiap tempat layanan berbeda-beda tetapi pada umumnya adalah menfasilitasi dan mempertemukan antara konselor dan konseli untuk melakukan bimbingan bahkan ada yang terintegrasi menggunakan web [1]. Pada umumnya tempat layanan kurang memperhatikan keahlian yang dimiliki oleh konselor sehingga sering ditemukan konselor menangani permasalahan konseli yang tidak sesuai dengan keahlian konselor hal ini dapat menyebabkan kurang tepatnya konselor dalam memberikan solusi. Selain itu umumnya konseli tidak memiliki hak untuk memilih konselor yang memiliki keahlian yang sesuia dengan permasalahan mereka. Selain itu selama ini tempat layanan tidak memberikan laporan jumlah layanan dan umpan balik dari konseli kepada konselornya padahal laporan tersebut dapat memberikan informasi kepada konseli tentang kwalitas dan pengalaman konselor dalam membatu menyelesaikan permasalahan kliennya.

Berdasarkan hal tersebut diatas maka diperlukan sebuah model sistem yang mampu mengatur proses penyelesaian permasalahan dalam memberikan layanan bimbingan konseling terhadap mahasiswa-mahasiswi. Penelitian ini menghasilkan model perancangan sistem informasi layanan bimbingan konseling berbasis penilaian kompetensi yang nantinya dapat digunakan dalam membangun sebuah sistem bimbingan konseling secara efektif dan efisien.

\section{METODOLOGI PENELITIAN}

Penelitian sejenis telah dilakukan oleh peneliti sebelumnya yaitu penelitian Prasetiawan, Dengan memanfaatkan media secara baik dan benar didalam memberikan pelayanan Bimbingan Konseling dapat memberikan dampak yang optimal didalam proses bimbingan. Media dapat membantu dalam menyampaikan gagasan maupun konsep secara kongkrit dari konselor serta dapat memberikan motivasi kepada konseli/peserta agar aktif didalam bimbingannya. Selain itu media juga dapat digunakan sebagai sarana untuk berfikir dan berbuat secara kritis. Berdasarkan itu maka dengan menggunakan media yang tepat maka kompetensi dari tujuan dasar yang telah ditentukan dapat tercapai dengan mudah [2].

Cahyo menjelaskan bahwa Salah satu bentuk terwujudnya "student support services" pada perguruan tinggi adalah keberadaan layanan Bimbingan Konseling yang telah terhubung dengan menggunakan media internet. Dengan adanya media bimbingan melalui internet maka pendaftaran maupun layanan dalam Bimbingan Konseling dapat dilakukan dari mana saja dan kapun saja. Model bimbingan dengan menggunakan media ini dapat memberika pelayanan secara maksimal apalagi bagi mahasiswa/i yang kesulitan konsultasi mealui tatap muka ataupun secara langsung. Model bimbingan onlin juga memudahkan konselor dan petugas administrasi dalam penyimpanan maupun pengarsipan dokumen layanan bimbingan. [3].

Apabila terjadi proses konseling yang dilaksanakan antara konselor dan konseli secara terpisah dengan memanfaatkan jaringan internet maka praktek semacam ini merupakan praktek konseling profesional. Konseling individu online, juga dikenal sebagai e-konseling [4], Cybercounseling, atau e-terapi. Konseling secara online telah muncul sejak manusia menemukan manfaat dari internet, namun relatif baru pada pengembangan kesehatan mental dimana seorang terapis atau konselor menyediakan sarana psikologis dan dukungan diInternet menggunakan format konseling individu. Definisi ini mencakup web, email, chat dan sebagainya. Dalam kondisi 
seperti ini memungkinkan terjadinya komunikasi antara dua pihak bisa lebih cepat, lebih efisien dan lebih nyaman [5].

Berdasarkan penelitian-penelitian tersebut diatas maka dapat disimpukan bahwa kebutuhan akan bimbingan konseling dengan menggunakan media online tidak menjadi hal yang aneh, hal ini dikarenakan hampir seluruh masyarakat saat ini baik muda, dewasa maupun tua dengan sangat mudah dapat mengguakan media online. Hal ini dapat kita ditemukan dengan banyaknya pengguna media sosial maupun group-group media sosial yang beranggotakan dari semua kalangan umur. Adapun penelitian ini akan merancang sebuah metode bimbingan konseling secara online dengan memanfaatkan penilaian konseli terhadap konselor, dengan adanya penilaian tersebut diharapkan nantinya calon konseli dapat memilih konselor yang terbaik. Selain itu dengan sistem penilaian ini konselor akan lebih bertanggungjawab dalam memberikan pelayanan dalam menyelesaikan masalah-masalah dari setiap konseli yang mereka hadapi.

Dalam merancang sistem bimbingan konseling online berbasis penilaian kinerja tersebut penulis menggunakan metode perancangan beorientasi obyek dengan memanfaatkan alat bantu UML (Unified Modeling Language). Adapaun detail dari tahapan penelitian ditunjukkan pada gambar 1.

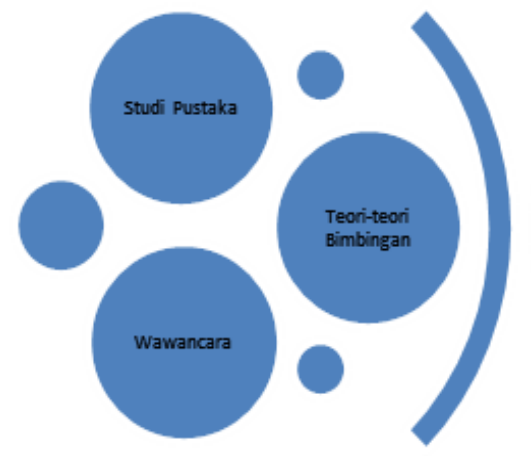

Pengumpulan Data dan
Referensi

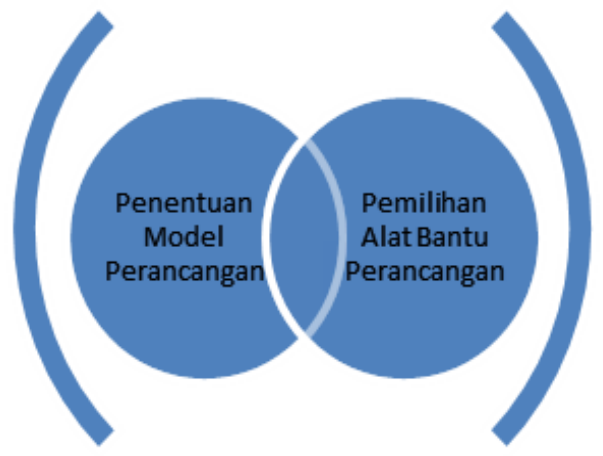

Perancangan

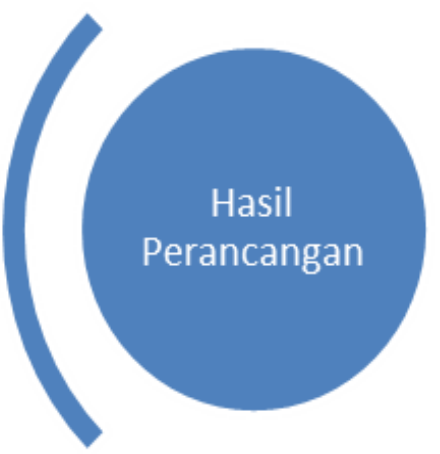

Hasil

\section{Gambar 1. Tahapan Penelitian}

Gambar 1. Menunjukkan urutan didalam proses penelitian dimana pada tahap pertama adalah pengumpulan data yang menggabungkan teori-teori tentang Bimbingan Konseling, studi pustaka serta wawancara dengan pengguna maupun penyedia layanan Bimbingan Konseling. Selanjutnya untuk ditahap yang kedua yaitu tahap perancangan yang dimuali dengan menentukan model perancangan lalu menentukan alat bantu perancangan. Sedangkan untuk tahap ahir dari penelitian ini adalah hasil dari perancangan sistem yang telah jadi sesuai dengan permasalahan yang akan diselesaikan serta dengan menggunakan model dan metode perancangan yang telah ditentukan.

\section{HASIL DAN PEMBAHASAN}

Pada tahapan awal sesuai dengan tahapan penelitian diatas adalah mengumpulkan teori, studi pustaka serta wawancara. Adapun tahap awal tersebut menghasilkan beberapa point penting diantaranya adalah pengguna dari sistem tersebut yaitu; 1. Konseli (klien), Konselor (seorang yang mempunyai keahlian dalam melakukan konseling/penyuluhan) dan petugas administrasi. Selanjutnya adalah tahap metode penentuan model perancangan, didalam proses bimbingan menggunakan media online nantinya akan ada interaksi antar obyek (pengguna sistem) oleh karena itu maka yang paling tepat didalam melakukan perancangan ini menggunakan model OOP dimana konsep ini yang paling menyerupai dengan dunia nyata, yaitu memungkinkan adanya komunikasi atau interaksi antar objek. Sehingga code yang dibuat lebih mudah dibaca. Untuk melakukan perancangan penggunakan model OOP maka alat bantu yang umum untuk dipergunakan adalam UML. Dalam merancang sebuah sistem berorientasi obyek dengan menggunakan UML maka diperlukan beberapa diagram yang dapat menggambarkan sistem tersebut diantaranya adalah diagram use case, class, sequence, activity, Communication, Deployment dan diagram state [6]. Namun didalam penelitian ini tidak semua diagramdiangram disajikan.

\subsection{Diagram Use Case}

Diagram ini digunakan untuk mengetahui semua fungsi yang ada didalam sebuah sistem serta siapa saja yang memiliki hak didalam tiap-tiap sistem yang ada. Diagram use case dipenelitian ini disajikan pada gambar 2 . 


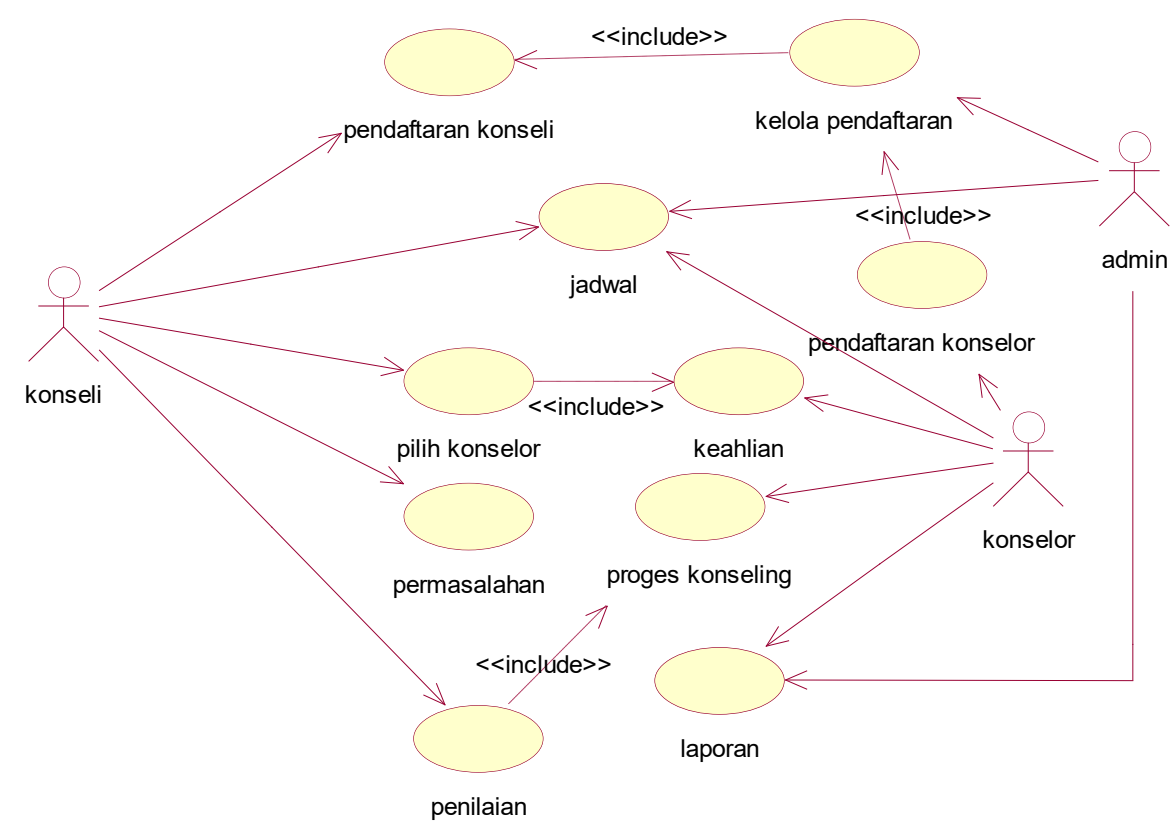

Gambar 2. Diagram Use Case

\subsection{Diagram Class}

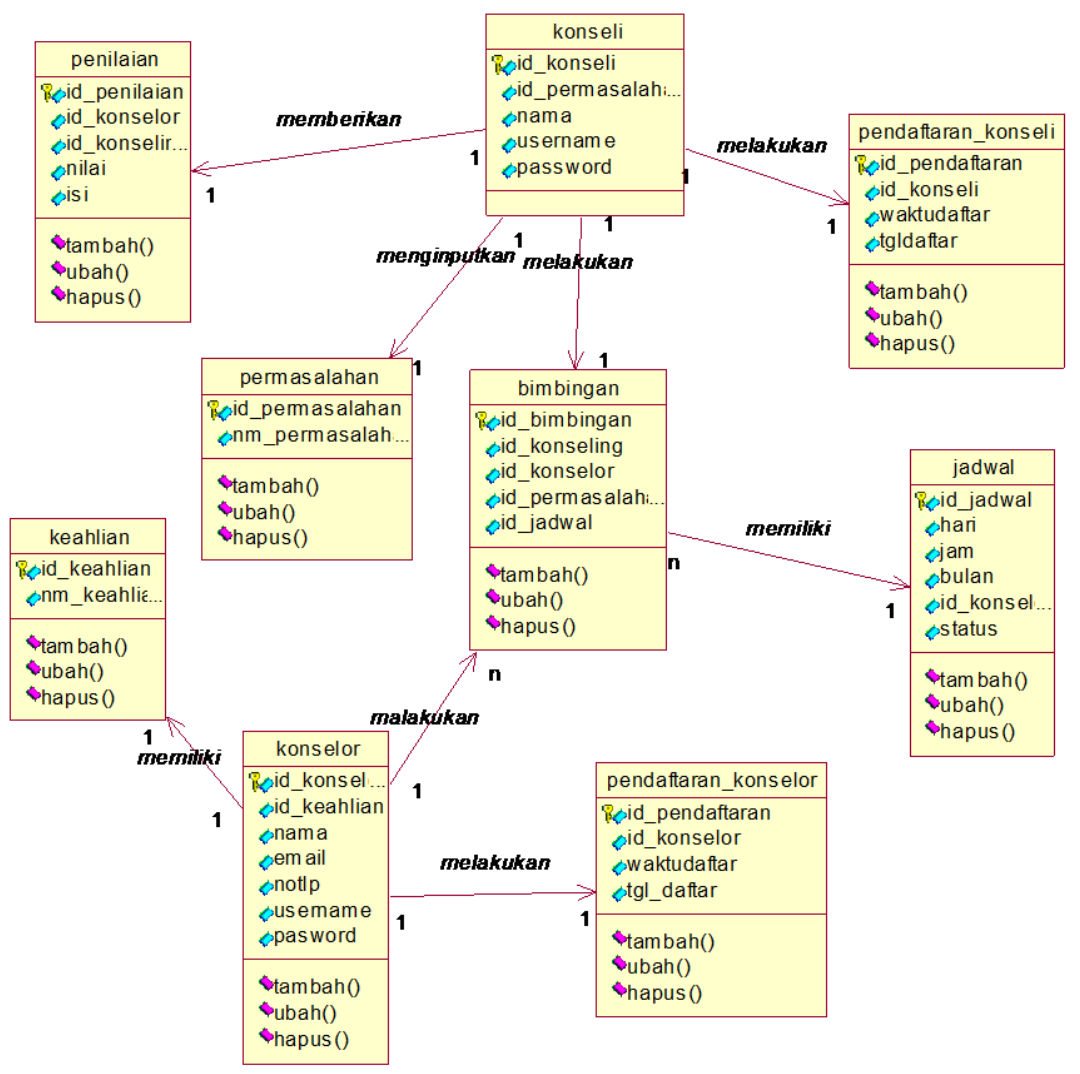

\section{Gambar 3 Diagram Class}

Diagram yang ditunjukkan pada gambar 3 merupakan diagram class dimana didalam diagram ini digunakan untuk menunjukkan difinisi-difinisi class dari struktur sistem yang akan dibangun. 


\subsection{Diagram Sequence}

Diagram ini menujukkan hubungan dan kolaborasi antar obyek sedangkan keguanaan dari diagram ini adalah untuk memperlihatkan rangkaian pesan dan interaksi yang dikirim antar obyek yang saling terhubung. Pada 4 menunjukkan salah satu dari diagram Sequence

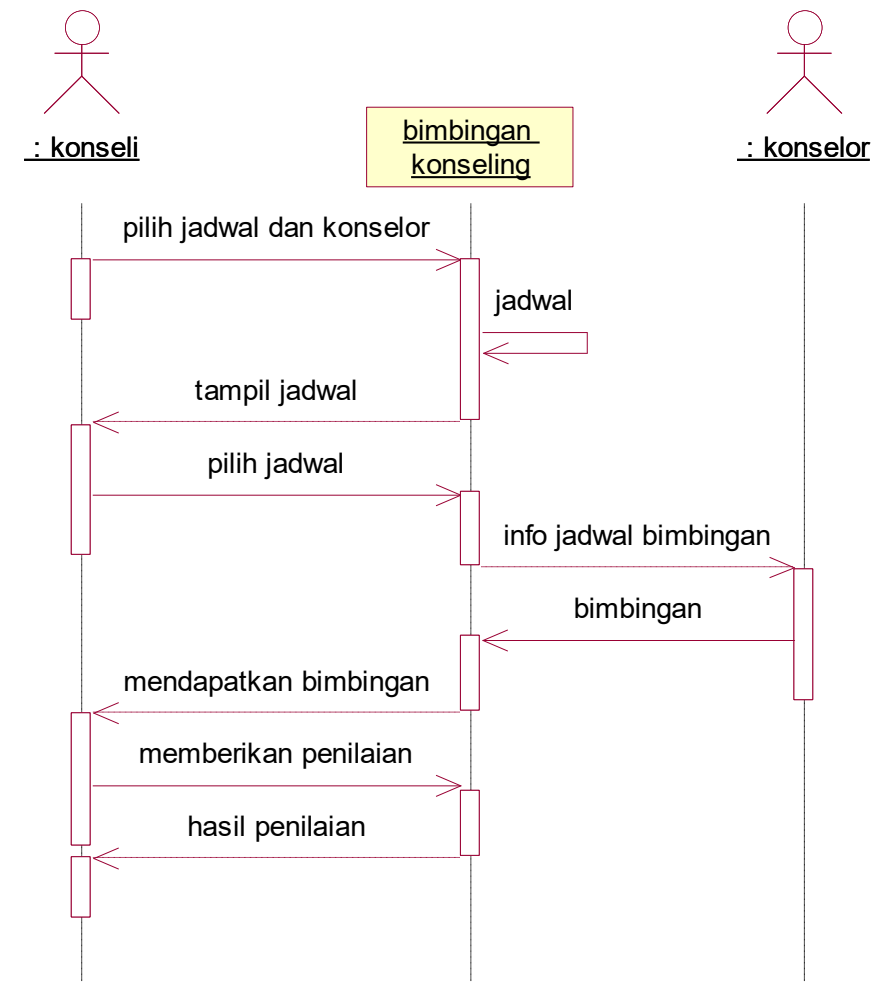

Gambar 4. Diagram Sequence

\subsection{Diagram Activity}

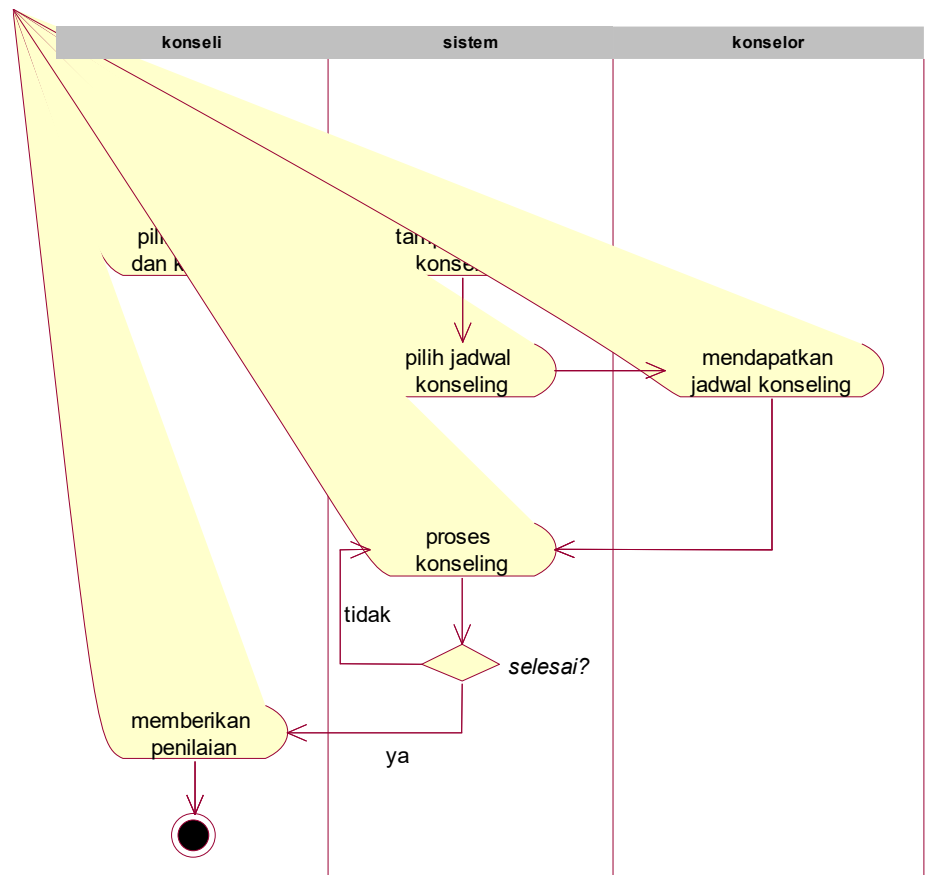

Gambar 5. Diagram Activity

Gambar 5 menunjukkan diagram Activity dimana diagram ini digunakan untuk menperlihatkan aktifitasaktifitas yang dapat dilakukan oleh sistem. 


\subsection{Diagram State}

Diagram State dipergunakan untuk menunjukkan kondisi-kondisi yang mungkin terjadi pasa sebuah obyek termasu eveni-event didalamnya, adapaun salah satu diagram state didalam peeancangan ini ditunjukkan pada gambar 6 berikut ini.

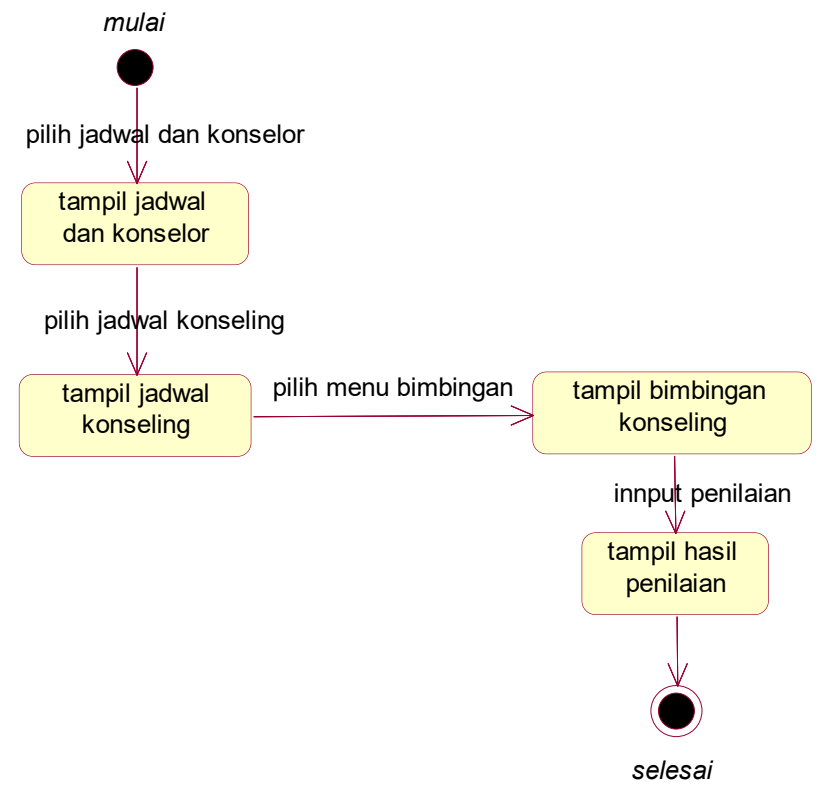

Gambar 6. Diagram State

\section{KESIMPULAN}

Adapun kesimpulan penelitian yang adalah sudah banyak penelitian tentang bimbingan konseling secara online, namun dari kebanyakan penelitian hanya merubah model penelitian yang semula konfensional menjadi online. Proses pendaftaran, pemiihan jadwal bimbingan serta proses konseling digantikan dengan media online. Sedangkan untuk penelitian ini menghasilkan perancangan aplikasi sistem bimbingan konseling online dengan menggunakan pemodelan UML. Selain itu penelitian ini menghasilkan model bimbingan konseling secara online dengan memberikan fasilitas penilaian kinerja konselor dalam memberikan pelayanan terhadap konseli. Penilian ini nantinya dapat dijadikan tolok ukur tingkat kesuksesan konselor dalam menyelesaikan permasalahan konseli yang mereka hadapi.

\section{UCAPAN TERIMA KASIH}

Atas terlaksananya penelitian ini penulis menyampaikan terima kasih kepada LPPM Universitas Muria Kudus yang telah berkenan untuk membiayai seluruh kegiatan yang ada didalam penelitian ini. Ucapan terima kasih pula disampaikan kepada PKPA yang bersedia untuk menjadi obyek dari penelitian ini. Selanjutnya kami juga menyampaikan terima kasih peada jurnal SITECH atas diterbitkannya makalah kami.

\section{DAFTAR PUSTAKA}

[1] Abdurrasyid dkk. 2017. "SISTEM E-KONSELING TERINTEGRASI WEB DALAM UPAYA MENINGKATKAN KUALITAS BIMBINGAN AKADEMIK MAHASISWA" JURNAL ILMIAH FIFO, Volume IX/No.1/Mei/2017, hlm. 14-22.

[2] Prasetiawan. $H, 2017$ "OPTIMALISASI MULTIMEDIA DALAM LAYANAN BIMBINGAN DAN KONSELING” Prosiding Seminar Bimbingan dan Konseling, Vol. 1, No. 1, 2017, hlm. 199-204.

[3] Cahyo, HWN. 2016, "BIMBINGAN KONSELING ONLINE “, Jurnal Ilmu Dakwah, Vol. 36(2) 2016 EISSN 2581-236X.

[4] Riswandha M.. N. dan Maulidyah N. 2017. "APLIKASI E-COUNSELING DALAM PEMANFAATAN LAYANAN BIMBINGAN DAN KONSELING UNTUK MENGATASI SISWA TERISOLIR MENGGUNAKAN METODE BACKWARD CHAINING (STUDI KASUS : DI SMP NEGERI 2 BANGIL)" JURNAL LINK VOL. 26/No. 1/Februari 2017, hlm. 3-18.

[5] Prasetya, AF. 2017. "MODEL CYBERCOUNSELING : TELAAH KONSELING INDIVIDU ONLINE CHATASYNCHRONOUS BERBASIS APLIKASI ANDROID” Prosiding Seminar Bimbingan dan Konseling Vol. 1, No. 1, 2017, hlm. 31-38.

[6] A.S Rosa dan Salahuddin M, (2011). "Modul Pembelajaran Rekayasa Perangkat Lunak. (Terstruktur dan Berorientasi Objek)", Modula, Bandung. 